\title{
Wonderful Digital Tourism Indonesia Dan Peran Revolusi Industri Dalam Menghadapi Era Ekonomi Digital 5.0
}

\author{
Ina Heliany ${ }^{\mathrm{a}, 1, *}$ \\ ${ }^{\text {a } U n i v e r s i t a s ~ M p u ~ T a n t u l a r ~}$ \\ ${ }^{1}$ Email : Inaheliany6@gmail.com* \\ * corresponding author
}

\section{ARTICLE INFO}

\section{Keywords}

Digital Tourism, the role of the Industrial revolution

\begin{abstract}
The rapid development of information technology in the past two decades has changed the various settings of human life. The appearance of the 5.0 industrial revolution in Japan had an impact in all fields, including in the tourism sector. This era was marked by the ease of access to information through digital media. In this regard, Indonesia also does not want to be defeated, but in Indonesia the new Industrial Revolution era in the Era 4.0. This is the reason for the emergence of the phenomenon of cultural shifts from manual systems to cyber and visual, as well as in the tourism sector, especially Indonesian tourists who are millennial generations.Therefore the government program after Indonesia's independence until now, continues to try to improve industrial development with various policies, especially the tourism industry which is a mainstay at this time. The research discusses whether the program used in order to improve the development of Indonesian tourism in the face of tourist destinations with the concept of "contemporary" through a digital approach and what is the role of tourism in facing the industrial revolution in the digital economy era.The research method used is a qualitative method. The results of the study were found to face current tourist destinations with 3 programs, namely Wonderful Startup Academy, Nomadic Digital Tourism and Destinations and the role of tourism in facing the digital era can be seen in marketing activities that can easily be accessed through internet media such as: websites, social media, online advertising, direct marketing e-mail, discussion forums and mobile applications. With the presence of digital marketing tourism, it is difficult to increase the country's foreign exchange earnings.
\end{abstract}

\begin{abstract}
ABSTRAK
Pesatnya perkembangan teknologi informasi dalam dua dekade terakhir telah mengubah berbagai pengaturan kehidupan manusia. Kemunculan revolusi industri 5.0 di Jepang berdampak di semua bidang, termasuk di sektor pariwisata. Era ini ditandai dengan kemudahan akses informasi melalui media digital. Dalam hal ini, Indonesia juga tidak ingin dikalahkan, tetapi di Indonesia era Revolusi Industri baru di Era 4.0. Inilah alasan munculnya fenomena pergeseran budaya dari sistem manual ke dunia maya dan visual, serta di sektor pariwisata, terutama wisatawan Indonesia yang merupakan generasi milenial. Oleh karena itu program pemerintah setelah kemerdekaan Indonesia hingga sekarang, terus berusaha untuk meningkatkan pengembangan industri dengan berbagai kebijakan, terutama industri pariwisata yang menjadi andalan saat ini. Penelitian ini membahas apakah program yang digunakan dalam rangka meningkatkan pengembangan pariwisata Indonesia dalam menghadapi tujuan wisata dengan konsep "kontemporer" melalui pendekatan digital dan apa peran pariwisata dalam menghadapi revolusi industri di era ekonomi digital . Metode penelitian yang digunakan adalah metode kualitatif. Hasil penelitian ditemukan menghadapi tujuan wisata saat ini dengan 3 program, yaitu Wonderful Startup Academy, Nomadic Digital Tourism and Destinasi dan peran pariwisata dalam menghadapi era digital dapat dilihat dalam kegiatan pemasaran yang dapat dengan mudah diakses melalui media internet seperti: situs web, media sosial, iklan online, email pemasaran langsung, forum diskusi, dan aplikasi seluler. Dengan adanya pariwisata pemasaran digital, sulit untuk meningkatkan pendapatan devisa negara
\end{abstract}




\section{PENDAHULUAN}

\subsection{Latar Belakang}

Belum lama ini kita mendengar konsep revolusi industri 4.0 dengan memanfaatkan data, teknologi blockchain, serta kecerdasan buatan. Akan tetapi Jepang sudah hadir dengan konsep Society 5.0., dengan konsep baru ini dinilai dapat menggantikan 4 versi sebelumnya yang hanya menitikberatkan pada produksi barang atau jasa.

Sebelum kita berbicara lebih jauh mengenai revolusi industri 5.0 ini, ada baiknya kita mengetahui apa dan bagaimana revolusi industri yang pernah terjadi di Dunia.

1. Pola Industri 1.

Pertama kali terjadi pasca ditemukan mesin uap, sehingga terjadinya perkembangan dan pertumbuhan yang besar dalam mesin-mesin industri di Inggris pada Tahun 1764. revolusi ini berdampak pada sector pertanian dan manufactur / industri terutama industri tekstil dan turunannya

2. Revolusi Industri 2

Terjadi diawal abad ke 19, penemuan pada masa ini lebih kearah listrik dan transportasi, kombinasi cara produksi dan perkembangannya ini berpengaruh pada teknologi terutama untuk industri besi, mesinmesin, minyak, kimia, kendaraan dan lain-lain. Seiring dengan meningkatnya keilmuan manusia, maka cara dalam mendapatkan makanan pun berubah, dari yang tadinya hanya mengumpulkan, kini beralih menjadi produksi makanan (pertanian). Inilah revolusi industri pertama yang terjadi khususnya pada sektor agraria.

3. Revolusi Industri 3

Dikenal masa otomasi, pada era inilah revolusi industri pertama kali dipopulerkan. Dimulai dari Inggris, perubahan pola kerja dari yang tadinya menggunakan tenaga manusia beralih dengan menggunakan mesin. Hal ini juga ditandai dengan penggunaan teknologi tinggi otomatis, menggunakan elektronik dan teknologi informasi. inilah yang berlangsung sampai hari ini. dimana mesin dan peningkatan kapasitas produksi dan software menjadi pendukung utama pada proses manufactur.

4. Revolusi Industri 4

Seiring dengan hal itu perkembangan teknologi informasi saat ini, software dan hardware serta pesatnya perkembangan penggunaan internet, maka oleh forum ekonomi dunia dapat dikatakan, inilah era yang sedang kita masuki sekarang, dimana sendi kehidupan manusia didominasi oleh kemajuan teknologi informasi. Internet, data, dan artificial intelligence adalah sederet teknologi yang menopang revolusi ini.

5. Revolusi Peradaban 5.0

Jika perkembangan teknologi sudah sebegitu majunya, lalu apalagi yang harus diperbaharui? Mungkin itu yang ada di pikiran sebagian orang, tapi tidak dengan ide yang dirumuskan oleh pemerintahan Jepang.

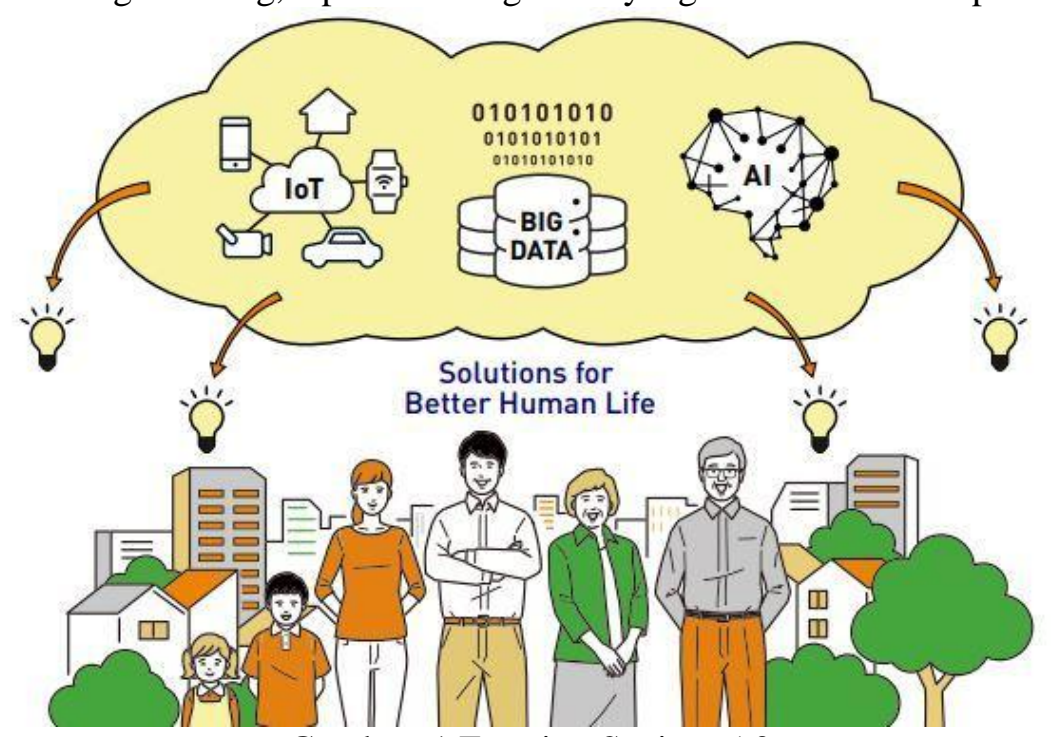

Gambar 1 Entering Society 5.0

Perkembangan teknologi yang begitu pesat, termasuk adanya peran-peran manusia yang tergantikan oleh kehadiran robot cerdas, dianggap dapat mendegradasi peran manusia. Hal ini yang melatar belakangi lahirnya Society 5.0 yang diperkenalkan di Kantor Perdana Menteri Jepang pada hari Senin, 21 Januari 2019. 
Melalui Society 5.0, kecerdasan buatan (artificial intelligence) akan mentransformasi big data pada segala sendi kehidupan serta the Internet of Things akan menjadi suatu kearifan baru, yang akan didedikasikan untuk meningkatkan kemampuan manusia membuka peluang-peluang bagi kemanusiaan. Transformasi ini akan membantu manusia untuk menjalani kehidupan yang lebih bermakna. Society 5.0 Secara sederhana, Society 5.0 dapat diartikan sebagai suatu konsep masyarakat yang berpusat pada manusia (human-centered) dan berbasis teknologi (technology based). Contoh aplikasi yang akan diterapkan oleh pemerintah Jepang dengan adanya konsep peradaban baru ini diantaranya sebagai berikut.

\section{Masalah}

- Jepang menghadapi masalah tingginya generasi tua yang mana pengeluaran untuk biaya pengobatan serta pelayanan nya semakin meningkat

- Kemajuan Jepang membuat minimnya ketersediaan tenaga buruh ahli dan tingginya biaya perawatan infrastruktur

\section{Solusi}

- Menggunakan data medical records untuk membantu mempercepat penanganan kesehatan

- Membuat sistem remot untuk pelayanan kesehatan

- Menggunakan AI dan robot sebagai perawat

- Sensor, AI, dan robot akan digunakan untuk membantu pemeliharaan jalan, terowongan, jembatan dan infrastruktur lainnya

Berbeda dengan di negeri sakura Jepang, Indonesia belum sampai pada era digital industri 5.0, saat ini Indonesia baru sampai pada era industri 4.0. Industri 4.0 adalah periode industri keempat yang dalam berbagai literatur dikatakan bahwa tahapan industri terbagai sebagai berikut:

1. Tahap 1: Industri yang sudah mengadosi mesin mekanis yang dimulai sejak ditemukannya mesin uap

2. Tahap 2: Industri yang sudah mengadopsi listrik yang ditandai dengan produksi masal (mass production);

3. Tahap 3: Industri yang sudah mengadopsi komputer dan otomatisasi;

4. Tahap 4: Industri yang sudah memanfaatkan ruang siber;

Kehadiran era revolusi industri keempat (Industri 4.0) sudah tidak dapat dielakkan lagi. Hal ini mengakibatkan perkembangan teknologi informasi yang begitu pesat dalam dua dekade terakhir dan berhasil merubah berbagai tatanan kehidupan manusia. Salah satu motor perubahan dari teknologi informasi adalah bidang bisnis yang terus berevolusi dan beradaptasi mengikuti laju perubahan. Aktivitas bisnis dalam proses produksi, distribusi, dan konsumsi secara nature terus mencari cara untuk menekan biaya dan mencari keuntungan sebesar-besarnya, sehingga efektif, efisien dan kemudahan akan terus diupayakan.

Begitu pula dengan industri pariwisata yang saat ini telah menduduki posisi nomor dua sebagai penyumbang devisa terbesar di Indonesia. Pencapaian hal tersebut bukanlah sesuatu yang tidak disengaja, beberapa strategi dilakukan oleh pemerintah untuk mencapai posisi tersebut salah satunya adalah strategi pemasaran /marketing dalam bidang pariwisata. Pariwisata seperti halnya industri lainnya, di mana hubungan antara produsen dan konsumen sering berlandaskan hubungan komersial. Pemerintah melalui Kementerian Pariwisata merancang strategi pemasaran yang terbagi menjadi strategi pemasaran/marketing, strategi media, strategi promosi, dan waktu promosi.

Oleh sebab itu program pemerintah setelah Indonesia merdeka sampai sekarang ini, terus berusaha meningkatkan pembangunan industri dengan berbagai kebijakan khususnya industri pariwisata yang menjadi andalan saat ini.

\subsection{Perumusan Masalah}

Berdasarkan latar belakang yang telah diuraikan diatas, maka permasalahan yang dibahas dalam penelitian ini adalah:

1. Program apakah yang digunakan dalam rangka meningkatkan perkembangan tourism Indonesia untuk menghadapi destinasi wisata berkonsep "kekinian" melalui pendekatan digital?

2. Bagaimanakah peran pariwisata dalam menghadapi revolusi industri di era ekonomi digital ?

\subsection{Tujuan Penelitian}

1. Untuk mengetahui program apakah yang digunakan dalam meningkatkan perkembangan tourism Indonesia untuk menghadapi destinasi wisata berkonsep "kekinian" melalui pendekatan digital 
2. Untuk mengetahui peran pariwisata dalam menghadapi revolusi industri di era ekonomi digital.

\section{TINJAUAN TEORI}

\subsection{Pengertian Tourism}

Kata pariwisata secara umum telah diterima sebagai terjemahan dari kata tourism (Inggris) atau toerisme (Belanda). Terjemahan tersebut, jika ditinjau dari segi etimologis (ilmu tentang asal muasal kata), sebenarnya kurang tepat. Menurut para ahli bahasa, kata pariwisata berasal dari bahasa Sanskerta dan terdiri dari dua suku kata, yaitu pari dan wisata. Pari berarti seluruh, semua dan penuh. Wisata berarti perjalanan. Dengan demikian, pariwisata dapat diartikan sebagai perjalanan penuh, yaitu berangkat dari suatu tempat, menuju dan singgah di suatu atau di beberapa tempat, dan kembali ke tempat asal semula.

Adapun pengertiannya, kata tourism mengacu pada suatu pengertian konseptual yang berkaitan dengan pengertian tour. Kata tour sendiri mengacu pada pengertian yang lebih teknis tentang salah satu bentuk kegiatan manusia. Sehubungan dengan itu, terjemahan yang lebih tepat dari kata tourism adalah kepariwisataan. Namun demikian, pada umumnya kata pariwisata masih dipergunakan sebagai terjemahan kata tourism sehingga sebenarnya merupakan suatu kerancuan peristilahan.

Bahasa Inggris mengenal kata tourism pada abad ke-19. Akhiran -ism yang melekat pada kata tour mengacu pada suatu paham atau fenomena yang terkait pada pengertian tour. Seperti halnya dengan akhiran -ism pada kata ideal sehingga menjadi idealism, pada atau capital menjadi capitalism, kata feodal menjadi feodalism, dan lain sebagainya. Di samping itu, kata tourism sering juga diartikan sebagai tour yang terorganisir (organized tour). Bahkan ada yang mengartikan sebagai komersialisasi kebutuhan manusia pada saat melakukan perjalanan.

Kata pariwisata muncul setelah diadakan Musyawarah Nasional Tourisme II di tretes, Jawa Timur tahun 1958 (sebelumnya digunakan istilah Tourisme). Pada saat itu kata tourisme diganti dengan Dharmawisata untuk perjalanan antara kota daerah tujuan wisata dalam negeri (Indonesia), dan Pariwisata untuk perjalanan antara benua atau negara. Untuk selanjutnya pada tahun 1960 lebih dikenal istilah pariwisata, pada saat Dewan Tourisme Indonesia berubah menjadi Dewan Pariwisata Indonesia. Sedangkan orang yang melakukannya digolongkan dalam dua kategori yaitu wisatawan mancanegara (asing) dan wisatawan nusantara (domestik).

Beberapa definisi pariwisata, sebagai berikut:

1. Pariwisata adalah "Berbagai macam kegiatan wisata dan didukung fasilitas serta layanan yang disediakan masyarakat setempat, sesama wisatawan, pemerintah, pemerintah daerah dan pengusaha.

2. Menurut Ketetapan MPRS No. I-II Tahun 1960: Kepariwisataan dalam dunia modern pada hakekatnya adalah suatu cara untuk memenuhi kebutuhan manusia dalam memberi hiburan rohani dan jasmani setelah beberapa waktu bekerja setelah mempunyai modal untuk melihat-lihat daerah atau negara lain., disebut pariwisata dalam dan pariwisata luar negeri .

3. World Tourism Organization /WTO : Tourism is activities of persons traveling to and staying in places outside their usual enviroment for not more than one consecutive year for leasure, business, and other purposes not related to the exercise of an activity remunerated from within the place visited.

4. Dalam International Association of Scientific Expert in Tourism / AIEST :Tourism is the sum of phenomena and relationships arising from travel and stay of non resident in so far as they do not lead to permanent resident and are not conected with any earning activity

5. Menurut Hunziker and Krapf tahun 1942: Tourism is the totality of the relationship and phenomena arising from the travel and stay of strangers, provided that they stay does not imply the establishment of a permanent residence and is not connected with a remunerative activities.

6. Menurut Weaver \& Lawton tahun 2006 : The sum of processes, activities, and outcomes arising from the interaction among tourist, tourist supplies, host governments, host communities, origin governments, universities, community collagues, and Non-government organizations ( NGO's ) in the process of atracting, hosting, transporting and managing tourist and other visitor.

7. Menurut Yoeti, 1985: Pariwisata adalah suatu perjalanan yang dilakukan untuk sementara waktu, yang diselenggarakan dari suatu tempat ke tempat lain, dengan maksud bukan untuk berusaha (bisnis) atau mencari nafkah di tempat yang dikunjungi, tetapi semata-mata untuk menikmati perjalanan tersebut guna pertamasyaan dan rekreasi atau untuk memenuhi keinginan yang beranekaragam

8. Direktorat Jenderal Pariwisata 1990 mengatakan : Pariwisata diartikan sebagai segala sesuatu yang berhubungan dengan wisata, termasuk pengusahaan objek dan daya tarik wisata serta usaha - usaha yang terkait di bidang tersebut. Wisata diartikan sebagai kegiatan perjalanan atau sebagian dari kegiatan 
tersebut yang dilakukan secara sukarela dan bersifat sementara untuk menikmati objek dan daya tarik wisata.

9. Pariwisata (tourism) adalah suatu peijalanan yang dilakukan untuk sementara waktu, yang diselenggarakan dari suatu tempat ke tempat lain, dengan maksud bukan untuk berusaha (business) atau mencari nafkah di tempat yang dikunjungi, tetapi semata - mata untuk menikmati perjalanan tersebut, guna bertamasya / rekreasi atau memenuhi keinginan yang beranekaragam.

10.MenurutRobert Meintosh dan Shashikant Gupta : Pariwisata adalah gabungan gejala dan hubungan yang timbul dari interaksi wisatawan, bisnis, pemerintah tuan rumah serta masyarakat tuan rumah dalam proses menarik dan melayani wisatawan-wisatawan serta para pengunjung lainnya.

Dalam definisi pariwisata tersebut, terdapat hal yang sama yaitu:

a. Perjalanan dilakukan untuk sementara waktu,

b. Perjalanan dilakukan dari suatu tempat (origin) ke tempat lainnya (destination),

c. Perjalanan harus selalu dikaitkan dengan pertamasyaan atau rekreasi,

d. Orang yang melakukan perjalanan tidak mencari nafkah di daerah yang dikunjungi dan semata-mata sebagai konsumen di tempat tersebut.

Kegiatan pariwisata mengalami perkembangan, di antaranya adalah adanya wisatawan yang melakukan kegiatan bisnis pada saat melakukan kegiatan wisata. Oleh karena itu point $d$., mengalami perubahan.Menurut Internasional Union of Official Travel Organizations (IUOTO), para wisatawan diartikan sebagai orang-orang yang sedang mengadakan perjalanan dalam jangka waktu minimal 24 jam dan maksimal 3 bulan di dalam suatu negeri yang bukan merupakan negari dimana biasanya ia tinggal. Mereka yang termasuk kategori wisata meliputi:

a. Orang-orang yang sedang mengadakan perjanalan untuk bersenang-senang, untuk keperluan pribadi, kesehatan, dan sebagainya,

b. Orang-orang yang sedang mengadakan perjalanan untuk maksud menghadiri pertemuan, mengikuti konferensi atau sebagai utusan berbagai macam badan atau organisasi,

c. Orang-orang yang sedang mengadakan perjalanan untuk kegiatan bisnis.

Menurut Saleh Wahab (1989), dalam kegiatan pariwisata terdiri dari tiga unsur yaitu manusia, tempat dan waktu. Manusia yaitu yang melakukan kegiatan pariwisata, ruang/tempat kegiatan pariwisata berlangsung dan waktu yaitu unsur tempo yang dihabiskan dalam perjalanan dan selama berdiam di daerah tujuan dalam kegiatan pariwisata.

Beberapa istilah yang terkait dengan pariwisata sebagai berikut :

1.Wisata yaitu perjalanan (travel),

2.Wisatawan: orang yang melakukan perjalanan (traveller),

3.Pariwisata: perjalanan yang dilakukan dari suatu tempat ke tempat lain (tour).

4.Picnic: suatu perjalanan bertujuan utnuk rekreasi yang, dilakukan tidak jauh dari tempat kediaman, direncanakan dan diorganisasikan secara sendiri atau bersama-sama dan perjalanan dilakukan kurang dari $12 \mathrm{jam}$.

5.Tour: perjalanan yang dilakukan dari suatu tempat ke tempat lain dengan suatu maksud, tetapi selalu mengandalkan perjalanan itu untuk tujuan bersenang-senang (pleasure) dan perjalanan dilakukan lebih dari 24 jam.

6.Trip/excursion: perjalanan yang dilakukan dalam rangka perjalanan wisata (tours) yang sedang dilaksanakan.

\subsection{Pengertian Revolusi Industri}

Merujuk beberapa literatur Kamus Besar Bahasa Indonesia (KBBI) Revolusi industri terdiri dari dua (2) kata yaitu revolusi dan industri. Revolusi berarti perubahan yang bersifat sangat cepat, sedangkan pengertian industri adalah usaha pelaksanaan proses produksi. Apabila ditarik benang merah maka pengertian revolusi industri adalah suatu perubahan yang berlangsung cepat dalam pelaksanaan proses produksi dimana yang semula pekerjaan proses produksi itu dikerjakan oleh manusia digantikan oleh mesin, sedangkan barang yang diproduksi mempunyai nilai tambah (value added) yang komersial. Revolusi Industri telah mengubah cara kerja manusia dari penggunaan manual menjadi otomatisasi atau digitalisasi.

Istilah "Revolusi Industri" diperkenalkan oleh Friedrich Engels dan Louis-Auguste Blanqui di pertengahan abad ke-19. Revolusi industri ini pun sedang berjalan dari masa ke masa. Dekade terakhir ini sudah dapat disebut memasuki fase ke empat 4.0. Perubahan fase ke fase memberi perbedaan artikulatif pada sisi kegunaaannya. Fase pertama (1.0) bertempuh pada penemuan mesin yang menitikberatkan (stressing) 
pada mekanisasi produksi. Fase kedua (2.0) sudah beranjak pada etape produksi massal yang terintegrasi dengan quality control dan standarisasi. Fase ketiga (3.0) memasuki tahapan keseragaman secara massal yang bertumpu pada integrasi komputerisasi. Fase keempat (4.0) telah menghadirkan digitalisasi dan otomatisasi perpaduan internet dengan manufaktur (BKSTI 2017).

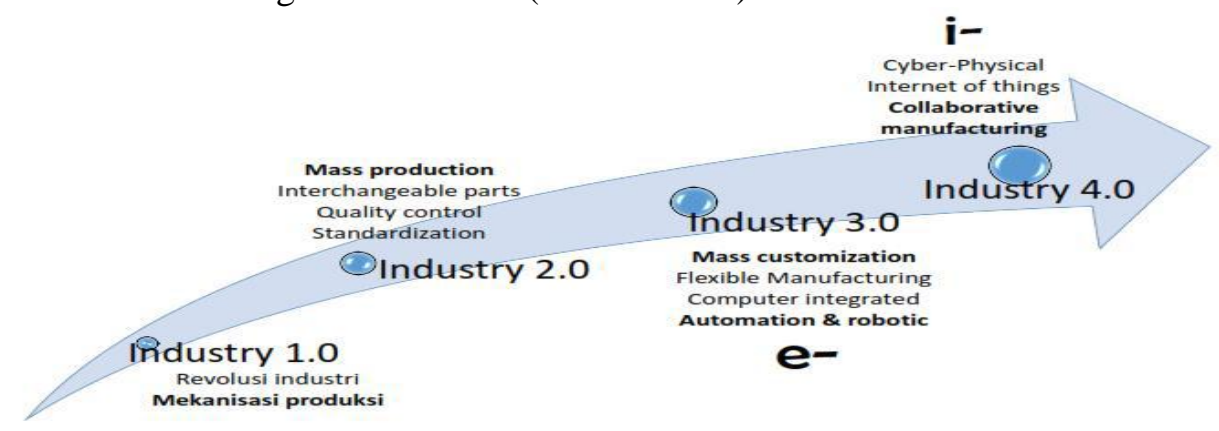

Gambar 2. Revolusi Industri

Revolusi Industri juga dikemukakan oleh Arnold Toynbee dalam bukunya Lectures On the Indutrial Revolution (London: Rivingston, 1884). Isi buku ini ialah deskripsi revolusi industri dan pengaruhnya terhadap kebijakan, mekanisasi produksi, budaya, dan tata keuangan dunia khususnya Eropa. Pemicu awalnya ialah penemuan mesin uap oleh James Watt. Berikutnya, Revolusi Industri 2.0 yang ditandai oleh penemuan listrik, dan Revolusi Industri 3.0 ditandai oleh penemuan komputer. Awal abad 21, penemuan Internet dan Teknologi Informasi (TI) memicu kelahiran Revolusi Industri 4.0.

Terminologi industri 4.0 pertama kali dikenalkan dalam Hannover Fair, Jerman pada tahun 2011 yang kemudian memperkenalkan istilah industri 4.0. Pada mulanya terminologi industri 4.0 adalah nama untuk inisiasi strategi teknologi pemerintah Jerman menuju Tahun 2020. Dalam literature review yang dilakukan oleh tim peneliti dari Universitas Dortmund, Jerman (Hermann, Mario Pentek, Tobias Otto dan Boris, 2015) ditemukan beberapa konsep kunci pada terminologi industri 4.0, yang kemudian menurut mereka konsep tersebut adalah komponen dari industri 4.0, yaitu: (1) Cyber-physical system (CPS); Internet of Things (IoT); Internet of Services (IoS); dan Smart Factory. Dari komponen kunci itulah kemudian Hermann, dkk mendefinisikan industri 4.0 sebagai berikut:

"we define Industrie 4.0 as follows: Industrie 4.0 is a collective term for technologies and concepts of value chain organization. Within the modular structured Smart Factories of Industrie 4.0, CPS monitor physical processes, create a virtual copy of the physical world and make decentralized decisions. Over the IoT, CPS communicate and cooperate with each other and humans in real time. Via the IoS, both internal and crossorganizational services are offered and utilized by participants of the value chain."

Menurut Prof. Dr. John Pieris "Revolusi Industri 4.0 memiliki 4 (empat) ciri. Yakni (1) simple atau sederhana dan anti rumit; dulu jika bermain game, hanya satu alat dan satu game; kini melalui teknologi Anroid, satu alat untuk ribuan bahkan jutaan games; (2) cepat (faster), kapan saja, dan dari mana saja di antar negara; Dahulu, kalau ingin lulus di Universitas di Amerika misal Harvard University harus pergi ke AS. Sekarang, daftar bisa via web-nya; (3) lebih murah (cheaper), dan (4) mudah diakses (accessible); akses adalah kekayaan informasi," ungkap Prof. Dr. John Pieris. Revolusi Industri 4.0. memicu perubahan berlangsung sangat cepat. Oleh karena itu, menurut Prof. Dr. John Pieris, Rakyat dan Pemerintah setiap Negara harus memiliki kecerdasan guna merespons Revolusi 4.0. Industri.

\section{METODE PENELITIAN}

Metode Penelitian yang digunakan adalah metode kualitatif. Kualitatif merupakan penelitian tentang riset yang bersifat deskriptif dan cendrung menggunakan proses analisis data tanpa menggunakan rumus dan angka-angka yang berasal dari informasi-informasi hasil studi kepustakaan akan tetapi angka atau data diambil dari instansi-instansi terkait maupun hasil pengamatan dalam penelitian yang telah ada dan dilakukan sebelumnya, kemudian data tersebut dikaitkan dengan landasan teori. 


\section{HASIL DAN PEMBAHASAN}

\subsection{Program yang digunakan dalam rangka meningkatkan perkembangan tourism Indonesia dalam menghadapi destinasi wisata berkonsep "kekinian" melalui pendekatan digital.}

Pariwisata merupakan salah satu sektor pembangunan yang saat ini sedang digalakkan oleh pemerintah. Tujuan pengembangan pariwisata di Indonesia terlihat dengan jelas dalam Instruksi PresidenRepublik Indonesia Nomor 9 Tahun 1969, khususnya Bab II Pasal 3, yang menyebutkan "Usaha pengembangan pariwisata di Indonesia bersifat suatu pengembangan "industri pariwisata" dan merupakan bagian dari usaha pengembangan dan pembangunan serta kesejahtraan masyarakat dan Negara. Menteri Pariwisata (Menpar) Arief Yahya mengatakan, perkembangan pariwisata Indonesia akan mengandalkan teknologi digital untuk mengakselerasi pertumbuhannya dan dalam menghadapi destinasi wisata berkonsep kekinian. Penggunaan teknologi digital dirasa paling tepat di era milenial saat ini."Untuk mengubah dunia secara radikal, ada dua cara, yaitu regulasi atau teknologi. Kita memilih teknologi digital untuk pariwisata agar Indonesia mampu menguncang dunia," Menpar menerangkan, lima perusahaan terbesar di dunia saat ini merupakan perusahaan berbasis digital (digital company). Karena itu, industri pariwisata pun harus mengandalkan teknologi digital. Tumbuhnya sektor pariwisata Indonesia juga didorong tingginya minat masyarakat melakukan perjalanan wisata, terutama oleh generasi milenial. Hasil survei dari Alvara Research Center menyebut, satu dari tiga generasi milenial Indonesia melakukan wisata minimal sekali dalam setahun.

Dari sisi strategi, pariwisata Indonesia berkembang dan maju berkat konsep tiga A (3A), yaitu atraksi, amenitas, dan aksesibilitas. Selama ini, promosi sudah dilakukan dengan gencar. Baik di dalam negeri maupun luar negeri. Baik secara offline maupun digital, terutama digital. Adapun dalam rangka perkembangan pariwisata Indonesia untuk menghadapi destinasi wisata berkonsep kekinian melalui pendekatan digital dapat dilakukan dengan tiga program, hal ini sejalan dengan penjelasan Menteri Pariwisata yang telah mensukseskan tiga program pengembangan pariwisata digital untuk kaum millenial yakni Wonderful Startup Academy, Nomadic Tourism dan Destinasi Digital.

a. Wonderful Startup Academy

Wonderful Startup Academy adalah program pengembangan startup business yang bergerak pada sektor pariwisata di Indonesia, hasil kolaborasi antara Kementerian Pariwisata, Kementerian Koperasi dan Usaha Kecil dan Menengah dan ICSB Indonesia. Salah satu tujuan program ini adalah menciptakan ekosistem agar Indonesia menjadi destinasi wisata utama mancanegara. Wonderful Startup Academy juga didukung oleh Indigo Creative Nation dan beberapa yayasan lainnya yang peduli dengan perkembangan startup business.Wonderful Startup Academy tahun 2018 ini memasuki batch ke-2 yang tentunya ada perbaikan dibandingkan batch sebelumnya seperti durasi program yang lebih singkat namun padat dan efektif, Startup peserta program telah menjalankan usahanya selama 2 tahun sehingga lebih memahami proses bisnisnya, memiliki traksi yang cukup baik serta proses seleksi yang melibatkan venture capital. Wonderful Startup Academy mencakup beberapa proses penting untuk perkembangan sebuah startup, seperti mentoring dari berbagai narasumber yang kompeten dan berbagi informasi tentang pariwisata Indonesia. Tak kalah pentingnya, program ini juga memberikan akses kepada para startup untuk menjalin kerjasama dengan para investor serta membuka akses pasar dengan pelaku bisnis pariwisata Indonesia dengan dukungan Kementerian Pariwisata Indonesia.

b. Nomadic Tourism

Nomadic tourism adalah gaya berwisata baru di mana wisatawan dapat menetap dalam kurun waktu tertentu di suatu destinasi wisata dengan amenitas yang portable dan dapat berpindah-pindah. Selain itu, gaya berwisata ini pun sangat cocok bagi suatu destinasi wisata yang sangat potensial namun daya dukung amenitas masih rendah. Maka, nomadic tourism ini akan menjadi solusi sementara yang sifatnya permanen bagi wisata tertentu di Indonesia. Dengan kata lain yang dimaksud nomadic tourism adalah wisata temporer baik akses maupun amenitasnya yang akan diterapkan untuk menjangkau destinasi alam potensial di kepulauan yang sulit dijangkau, seperti Maluku misalnya.Menteri Pariwisata Arif Yahya dalam siaran tertulisnya menambahkan bahwa nomadic tourism itu mudah dan murah. Hanya perlu ada atraksi pariwisata yang menarik, maka pengadaan akses dan amenitas bisa dilakukan dengan menggunakan bahan baku yang bisa dipindah. Misalnya 
pembangunan glamp camp atau dengan live on board, caravan, dan home pod. Caravan ini merupakan hotel yang didesain menggunakan mobil karavan. Hotel ini pun bisa berpindah-pindah secara harian atau pun mingguan untuk mencari spot destinasi wisata terindah. Dengan adanya hotel Caravan, wisatawan bisa memanfaatkannya untuk menikmati keindahan alam namun sangat minim penyediaan amenitas. Sedangkan tren wisata dengan cara glamping (glamour camping) memang sudah diperkenalkan ke pariwisata Indonesia. Hampir sama halnya seperti camping pada umumnya, namun akomodasi camp yang diberikan dipastikan sangat nyaman senyaman bermalam di hotel berbintang.

Konsep nomadic tourism yang ditawarkan Kementrian Pariwisata adalah Home Pod. Secara konsep, Home Pod ini menawarkan konsep bermalam berpindah-pindah juga seperti Caravan. Yang membedakan, jika hotel Caravan akan berpindah setelah sehari atau semingguan, maka Home Pod bisa bertahan 6 bulan atau pun setahun. Home Pod ini merupakan rumah telur yang memiliki kerangka keras dengan berat hampir 2 ton yang bisa dipindahkan.Untuk menjalankan program yang dicanangkan Kementrian Pariwisata ini kemungkinan akan menemui beberapa kendala seperti perizinan penggunaan caravan, izin penggunaan Taman Nasional, dan bagaimana memetakan lokasi tempat diaplikasikannya konsep pariwisata nomadic tourism ini. Namun, segala kendala tersebut telah dikomunikasikan dengan pihak-pihak terkait. Harapannya, masing-masing sektor bisa mensupport pariwisata Indonesia.Nomadic Tourism ini sendiri bukanlah gaya berwisata yang baru. Style liburan ala nomadic traveler ini sudah diterapkan di beberapa negara seperti Mongolia dan Maldives.

c. Destinasi Digital

"Destinasi Digiital" itu. Dikatakan Destinasi Digital, karena destinasi itu terbentuk dan menjadi benarbenar destinasi wisata, setelah dipromosikan melalui media social. Format content-nya sangat digital, menggunakan gambar atau foto, video dan text, dan diposting dengan Media Sosial. Media yang sangat digital. Media tempat anak-anak millenials melakukan search and share. Kementerian Pariwisata akan menggebraak dunia dengan promosi wisata melalui instagram.Sekarang ini melalui Generasi Pesona Indonesia (Genpi) berhasil menciptakan tujuh destinasi wisata digital (digital tourism) serta paket wisata digital 100 tempat destinasi Indonesia yang indah dan fotogenik.

Adapun beberapa jenis objek wisata yang ada di Indonesia, antara lain:

1. Wisata Alam.

Indonesia memiliki kawasan terumbu karang terkaya di Dunia dengan lebih dari $18 \%$ terumbu karang di dunia. Serta lebih dari 3000 species ikan, 590 jenis karang batu dan banyak lagi objek wisata yang sangat menarik. Seperti Raja Ampat di Papua Barat, Teluk Kiluan di Lampung dan Pulau Derawan.

2. Wisata Belanja.

Wisata di Indonesia terbagi dengan pusat belanja modern dan tradisional. Contohnya pusat belanja modern seperti mall dan setiap tahun selalu ada Jakarta Great Sale yang memberikan diskon secara besar-besaran. Sedangkan pasar tradisional seperti Pasar Beringharjo di Jogjakarta, Pasar Klewer di Solo atau Pasar Terapung di Sungai Barito Banjarmasin.

3. Wisata Budaya.

Berdasarkan data sensus 2010, Indonesia terdiri dari 1.128 suku bangsa. Sehingga Indonesia terkenal dengan kayanya budaya tradisional, misalnya sendratari Ramayana yang sering di pentaskan di Candi Prambanan. Tari Kecak, Tari Legong di Bali. Serta tari Piring dari Padang.

4. Wisata Religi.

Wisata Religi di Indonesia cukup banyak, misalnya Wisata Religi ke makam Walisongo, atau kebeberapa peninggalan sejarah yang menggambarkan agama Budha di Candi Borobudur.

Tiga program pengembangan pariwisata digital untuk kaum millenial ini yakni Wonderful Startup Academy , Nomadic Tourism dan Destinasi Digital sangat sesuai dengan jargon penting upaya Go Digital oleh Kementerian Pariwisata Indonesia (Pariwisata, 2018) yaitu: 
1. The More digital, the more personal adalah semangkin digital kita mempromosikan pariwisata secara personal kita dapat mengetahui demografi, psikogafi dan perilaku konsumen secara efektif dan terukur. seperti Gambar 3

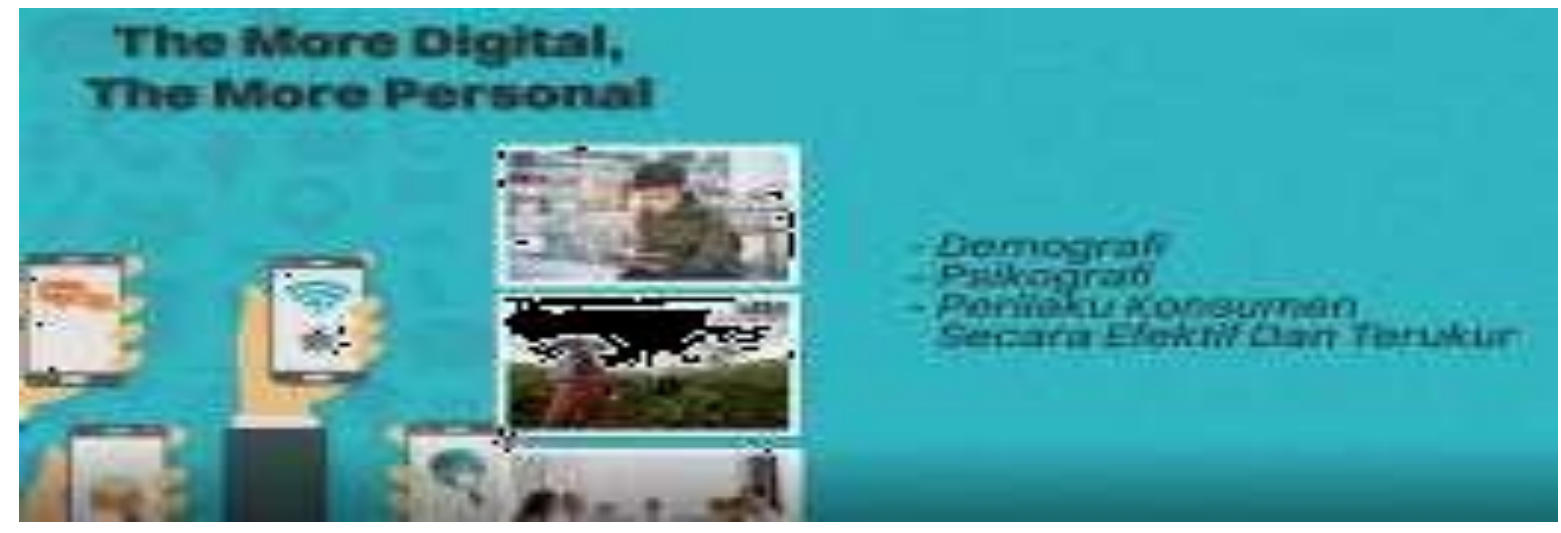

Gambar 3. The More Digital, The More Pesonal

2. The More digital, the more professional adalah semakin digital kita semakin professional mempromosikan pariwista seperti Gambar 4 mengintegrasikan paid, owned dan social media menggunakan bigdata.

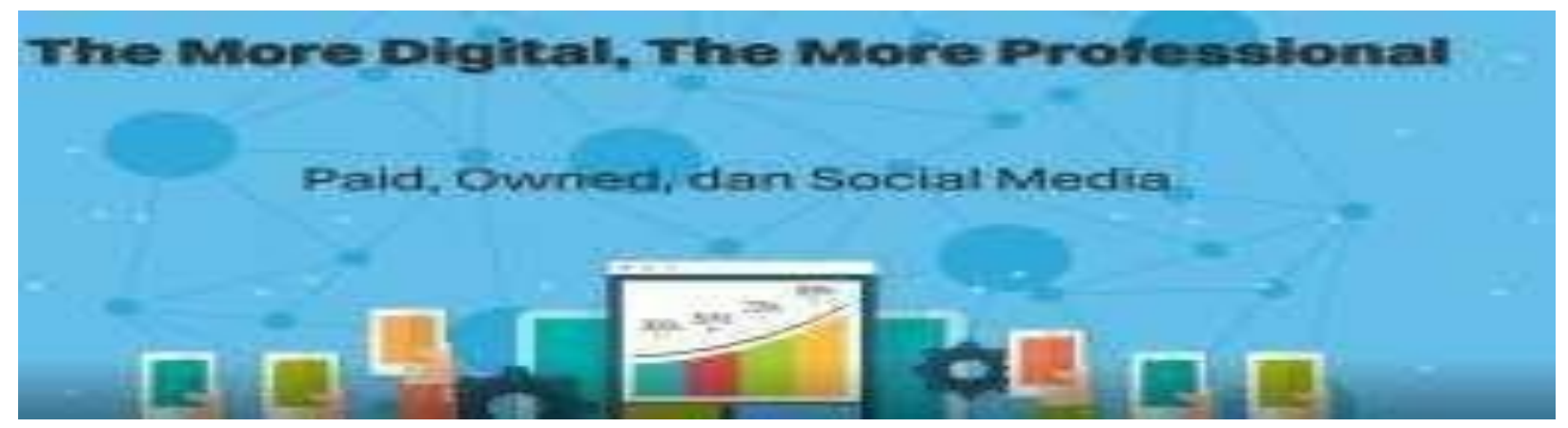

Gambar 4 The More Digital, The More Pofessional

3. The More digital, the more global adalah semakin digital kita maka kita mengjakau konsumen berbagai negara seperti pada Gambar 5.

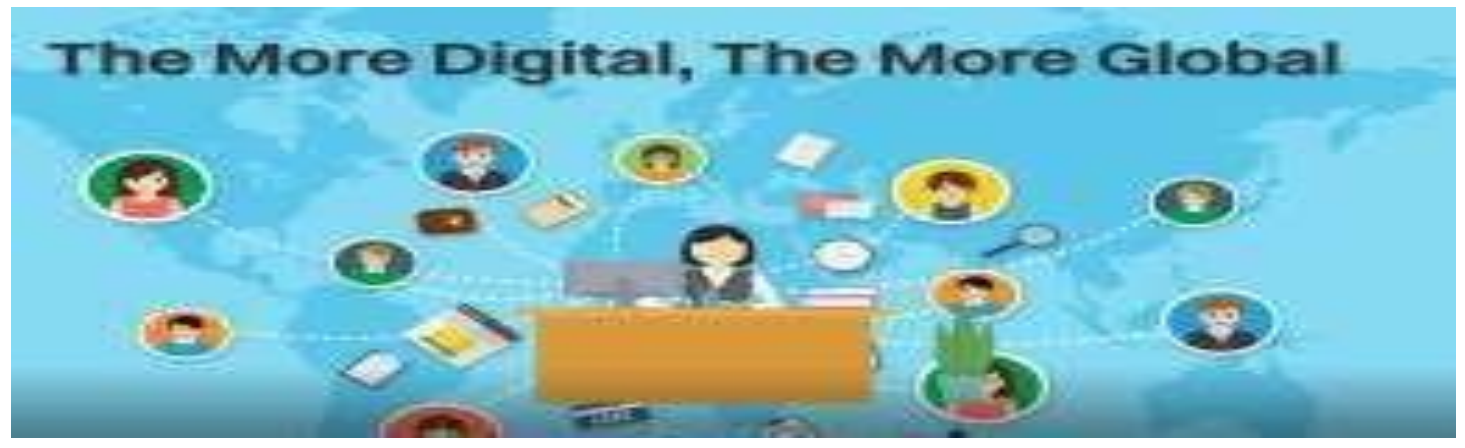

Gambar 5 The More Digital, The More Global

Diharapkan dengan tiga program pengembangan pariwisata digital untuk kaum millenial ini yakni Wonderful Startup Academy, Nomadic Tourism dan Destinasi Digital, industri pariwisata Indonesia menjadi lebih terkenal di mancanegara dan dapt memberikan tambahan devisa bagi negara.Hal ini terbukti dengan adanya kenaikan Jumlah kunjungan wisatawan mancanegara atau wisman ke Indonesia Februari 2019 naik 6,12 persen dibanding jumlah kunjungan pada Februari 2018, yaitu dari 1,20 juta kunjungan menjadi 1,27 juta kunjungan. Begitu pula, jika dibandingkan dengan Januari 2019, jumlah kunjungan wisman pada Februari 2019 mengalami kenaikan sebesar 4,80 persen. Secara kumulatif (Januari-Februari 2019), jumlah kunjungan wisman ke Indonesia mencapai 2,48 juta kunjungan atau naik 8,19 persen dibandingkan dengan jumlah kunjungan wisman pada periode yang sama tahun 2017 yang berjumlah 2,30 juta kunjungan. 
Kunjungan wisman ini berdasarkan data BPS juga mengalami kenaikan sebesar 3,36\% melalui jalur udara, dan jalur laut serta darat. Kenaikan wisatawan mancanegara ke Indonesia sedikit banyak dipengaruhi oleh era digital yang semakin lama semakin berkembang dengan dibuatnya inovasi-inovasi baru dalam menghadapi wisman generasi millenial yang kekinian.

\subsection{Peran pariwisata dalam menghadapi revolusi industri di era ekonomi digital}

Digital Marketing Pariwisata adalah usaha untuk mempromosikan dan memasarkan sebuah daerah/daya tarik wisata dengan menggunakan media digital. Berdasarkan informasi pengguna internet, Indonesia masuk peringkat 6 besar dunia sampai tahun 2018 sepeti gambar 6. (Kominfo.go.id, 2018).

\begin{tabular}{|c|c|c|c|c|c|c|}
\hline & 2013 & 2014 & 2015 & 2016 & 2017 & 2018 \\
\hline 1. China- & 620.7 & 6436 & 669.8 & 700.7 & 7362 & 777.0 \\
\hline 2. Us - & 245.0 & 2529 & 259.3 & 264.9 & 2697 & 2741 \\
\hline 3. trnctia & 1672 & 2156 & 2523 & 283.8 & 313.8 & 346,3 \\
\hline 4. Brazl & 902 & $107>$ & 733.7 & 119.8 & 123.3 & 125,9 \\
\hline S saparn & 1000 & 1027 & $703: 6$ & 1045 & 1050 & 705.4 \\
\hline 6. Indonesta & 728 & 83.7 & 93.4 & 102.8 & 172.6 & 123.0 \\
\hline 7 Rurssia & 20.5 & 829 & 67.3 & 91.4 & 9.4 .3 & 96.0 \\
\hline 8. Germany & 59.5 & 61.6 & 622 & 52.5 & 627 & 62.7 \\
\hline 9. Mexcico & 53.7 & 594 & 65.1 & 70.7 & 75.7 & 80.4 \\
\hline 10. Nigeria & 51.8 & 577 & 632 & 69.7 & 76.2 & 8.4:3 \\
\hline 17 uk $\cdots$ & 488 & 50.7 & 573 & 52.4 & 53.4 & $54: 3$ \\
\hline 12 France & 48.8 & 49.7 & 50.5 & $51: 2$ & 51.9 & 52,5 \\
\hline 13. Philipoines & 423 & 48.0 & 53.7 & 59.1 & 64.5 & 69.3 \\
\hline 14. Turkey & 36.6 & 410 & 447 & 477 & 50.7 & 535 \\
\hline 15 Vietnarm & 36.6 & 40.5 & 4.4 & 482 & 52,7 & 55.8 \\
\hline 16: South Korea & 40.1 & 40.4 & 40.6 & 40.7 & 40.9 & 41.0 \\
\hline 17. Esypt & 34.1 & 360 & 383 & 40.9 & 43.9 & 47.4 \\
\hline 18. Itally & 3.4 .5 & 358 & 36.2 & 372 & 37.5 & 37.7 \\
\hline 19. Spain & 30.5 & 31.6 & 323 & 33.0 & 335 & 33.9 \\
\hline 20. Canada & 27.7 & 28.3 & $28: 8$ & 29.4 & 29.9 & 30.4 \\
\hline 21. Argentima & 25.0 & 27.1 & 290 & 298 & 30.5 & 31.1 \\
\hline 22 Colombia & 24.2 & 26.5 & 28.6 & 29.4 & 30.5 & 31.3 \\
\hline 23. Thailand & 227 & 243 & 260 & 27.6 & 29.7 & 30.6 \\
\hline 24. Pollarid & 226 & 229 & 233 & 237 & 240 & 24.3 \\
\hline 25. South Africa & 20.7 & 227 & 25.0 & 27.2 & 292 & 30.9 \\
\hline Worlatweide".t. & 2692.9 & 2.892 .7 & 3.072 .6 & $3,246.3$ & 3.419 .9 & $3,600,2$ \\
\hline \multicolumn{7}{|c|}{ 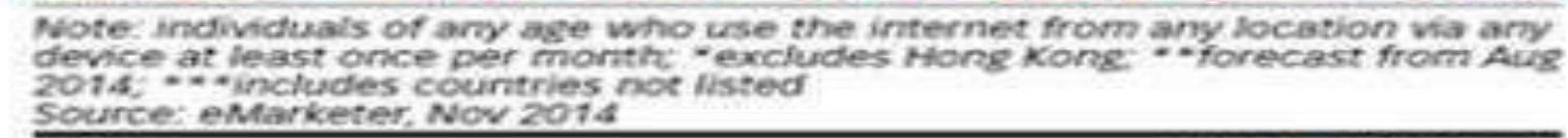 } \\
\hline
\end{tabular}

Gambar 6.

Data dari Kementerian Pariwisata menunjukan bahwa 63\% dari keseluruhan kegiatan travelling saat ini dicari, dipesan dan dijual secara online dan 50\% dari penjualan online travel menggunakan lebih dari satu gadget, bahkan sekitar 200 lebih ulusan mengenai travelling permenitnya telah diposting di TripAvisor.

Memang Indonesia saat ini tidak secanggih negara tetangganya yang sudah lebih dulu menerapkan Big data seperti jepang, jeman dan Amerika Serikat. Akan tetapi untuk mengejar ketertinggalan, Indonesia sudah mulai menerapkan era digital khsususnya dalam bidang pariwisata hal ini terlihat pada gambar 7 dibawah ini. 


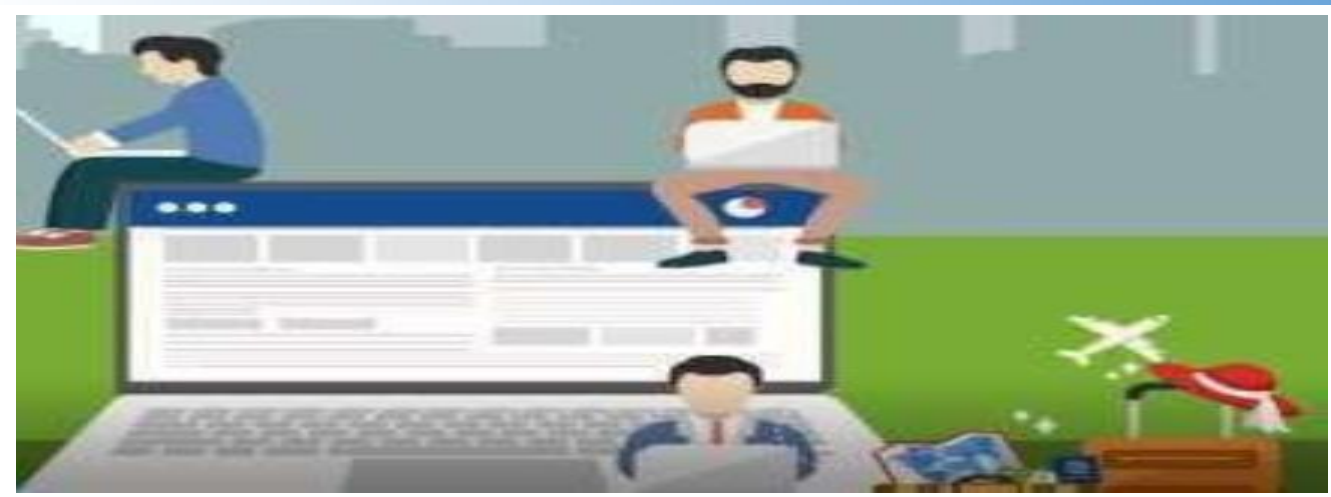

Gambar 7

Peran pariwisata dalam menghadapi era digital dapat dilihat pada aktivitas marketing yang dengan mudah dapat diakses melalui media internet seperti : website, social media, online advertising, email direct marketing, forum discussion dan mobile applications. Peranan digital marketing sangat berpengaruh untuk mendatangkan pariwisata, dan yang sedang gencar-gencarnya adalah dengan di terapkannya E-tourism (IT enabled tourism / electronic tourism) yaitu suatu sistem dalam bidang pariwisata, berupa berbagai jasa layanan pariwisata kepada customers dalam bentuk telematika dan menjadikan penyelenggaraan pemasaran pariwisata lebih mudah diakses. E-tourism adalah sebuah cara promosi yang modern dan informasi terkini mengenai pariwisata yang dicari oleh wisatawan, seperti obyek wisata, hotel, agen perjalanan, dan eventevent yang dapat diakses 24 jam kapanpun, dimanapun dan siapapun. E-tourism adalah sebuah sistem interaktif online yang mempermudah wisatawan untuk mendapatkan informasi dan melakukan pemesanan beberapa dari elemen pariwisata yang tersedi seperti hotel dan agen perjalanan. E-tourism memiliki prinsip yang diselaraskan dengan pemanfaatannya yaitu dalam peningkatan pembangunan pariwisata. Ada tiga unsur yang menjadi prasyarat dari e-tourism yaitu ICT (Information and Communication Technologies), Tourism dan Business, serta dukungan dari pemerintah. e-tourism yang dapt dikembangkan seperti Gambar 8.

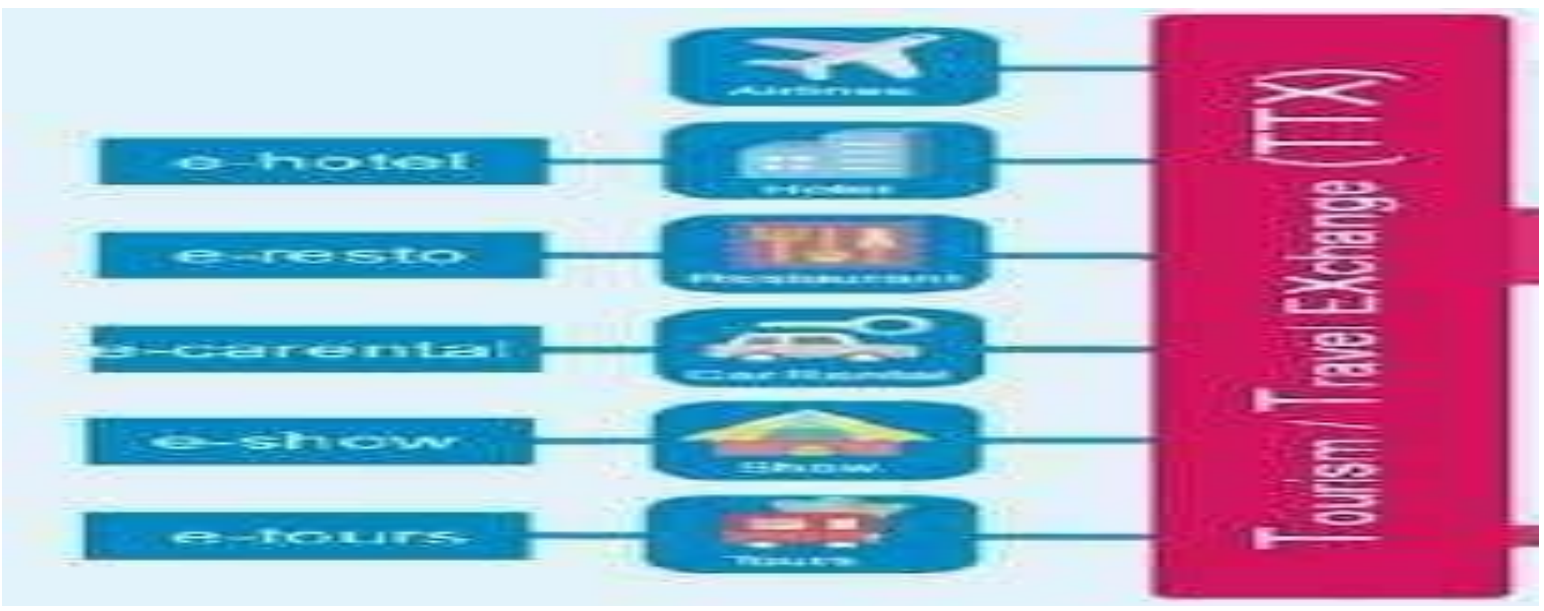

Gambar 8. E- tourism

e-tourism yang bisa di aplikasikan di digital marketing ada 5 (lima)

1. Website

Website atau web adalah halaman informasi yang disediakan melalui internet sehingga bisa diakses diseluruh dunia selama terkoneksi internet, website ada yang dinamis statis. ditemukan di search engine seperti di google, yahoo, bing atau yang search engine yang lainnya. Website e-tourism adalah website seperti yang berisi informasi konten, gambar atau video seperti tempat wisata, hotel, tours dan lain-lain seperti pada Gambar 9. 
Pencarian hotel yang ada di Bali Gambar 10. Ataupun ada website focus pada salah satu bidang usaha seperti hotel, travel, rencart atau yang lainnya gambar 11 .

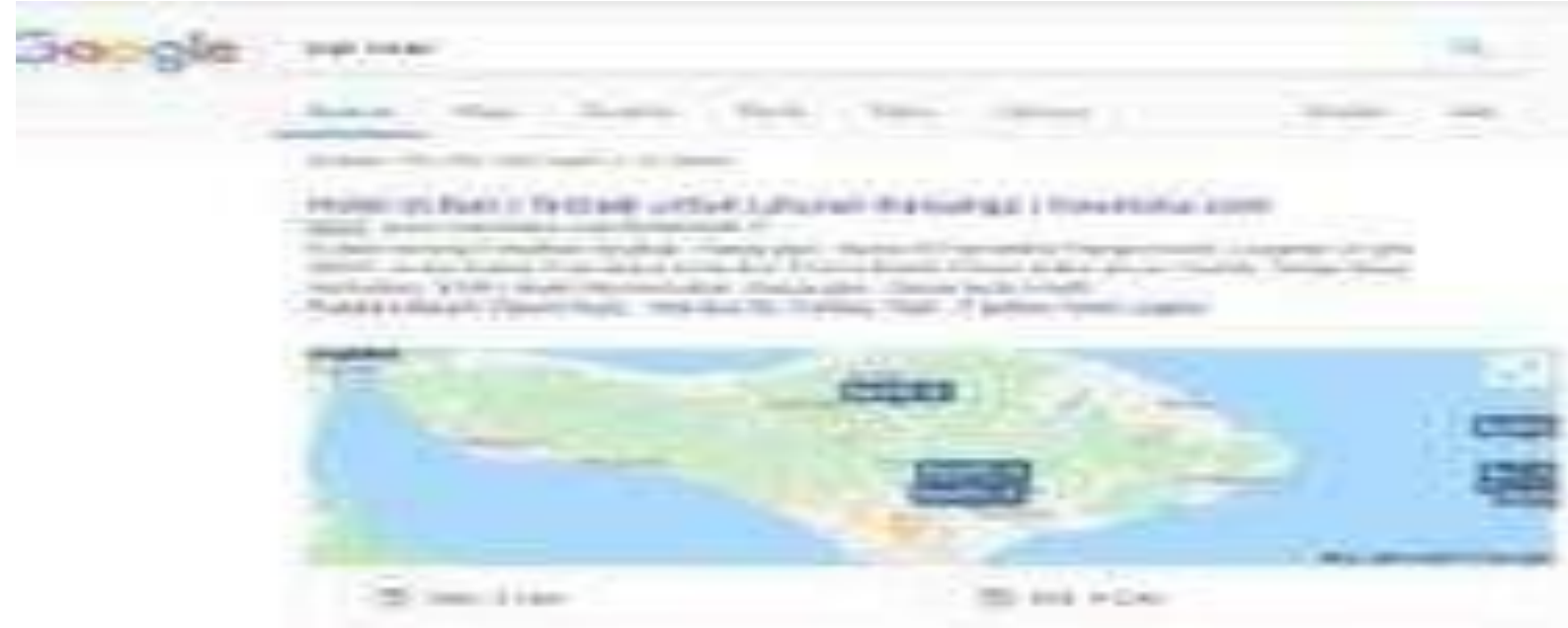

Gambar 9

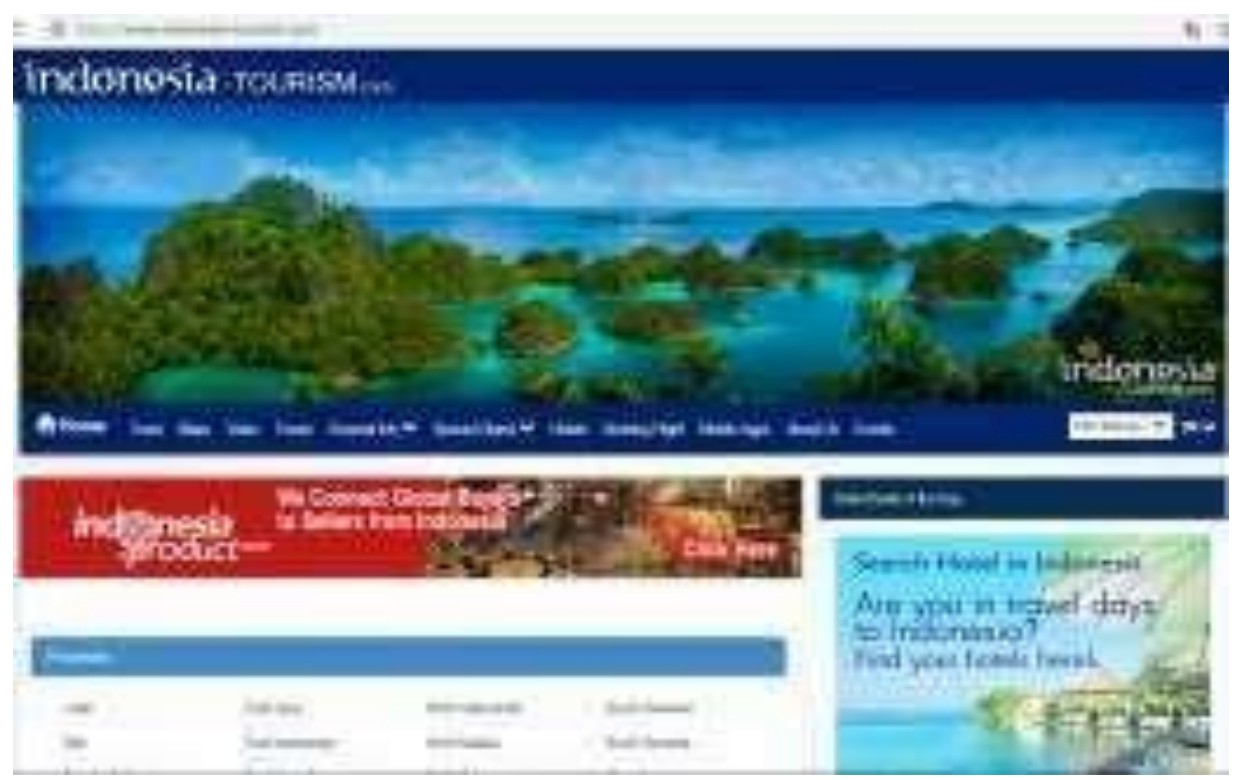

Gambar 10

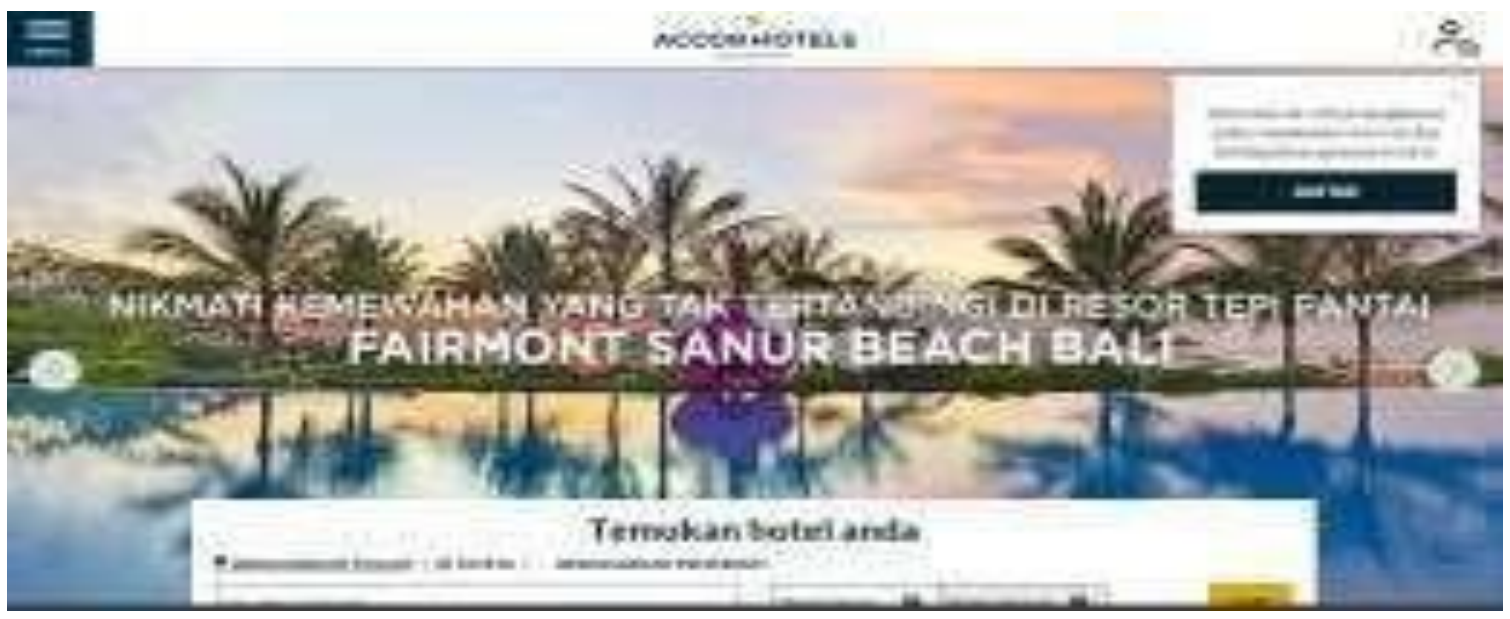

Gambar 11 


\section{Social Media}

Social media adalah media online yang para penggunanya bisa berbagi, berpartisipasi dan menciptakan isi konten text, gambar, vidoe maupun buat streaming online. Media sosial seperti gambar 12

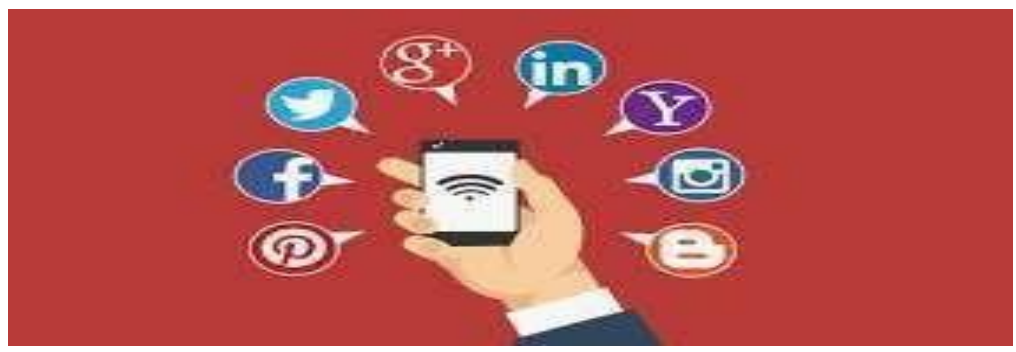

Gambar 12 Media Sosial

Tiga Media sosial yang populer yang digunakan pada digital pariwisata

a. Facebook

b. Instagram

c. Twitter

d. Youtube

Media sosial ini sebelum sebagai ajang mencari pertemanan, chating, sharing video. Perkembang sosial media sebagai media digital di dunia bisnis sebagai media promosi, follower dengan mengupload gambar-gambar atau konten yang akan di promosikan secara webbase maupun mobile. Dengan adanya media sosial untuk mempromosikan pariwisata lebih cepat dan realtime dan bisa di lihat oleh pengguna sosial media.

\section{Online Advertising}

Online advertising adalah iklan yang dibuat secara online atau website untuk menarik pelanggan. Contoh penerapan online advertising adalah Gambar 13.

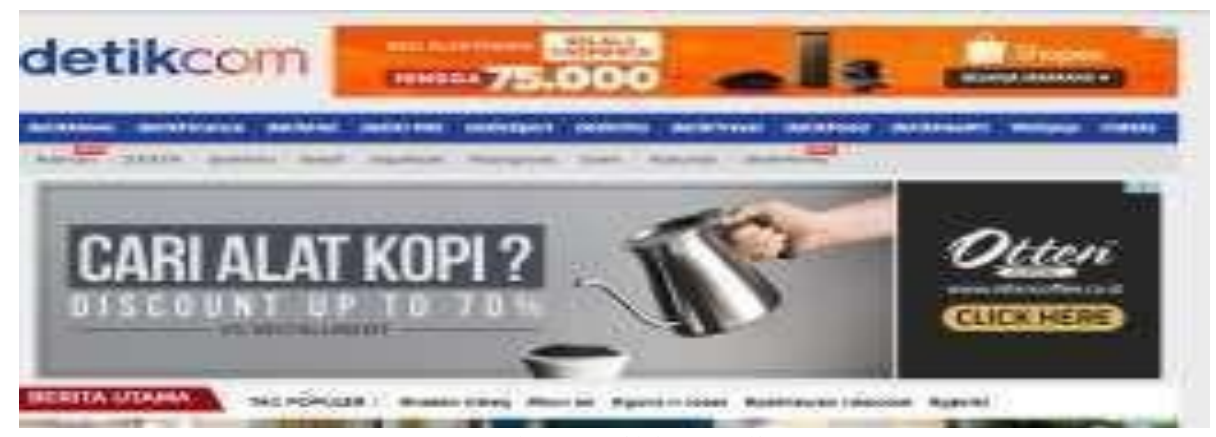

Gambar 13 iklan online

Dengan adanya media iklan online jadi kita lebih cepat memasarkan pariwisata dengan menaruh iklan di website-webiste yang menyediakan tempat pasang iklan online.

\section{Forum discussion.}

Forum discussion adalah kumpulan forum secara online yang memuat data, gambar, animasi, suara, video atau gambungan dari semuanya yang terhubung dalam sebuah jaringan. Hyperlink dimuat bersifat searah. Web forum memiliki topik atau trade untuk dibahas yang dibuat dengan langkah update info dalam web tersebut oleh pembuat web forum tersebut. Topik tersebut ditanggapi atau direspon oleh anggota forum yang ada diwebsite seperti Gambar 14.

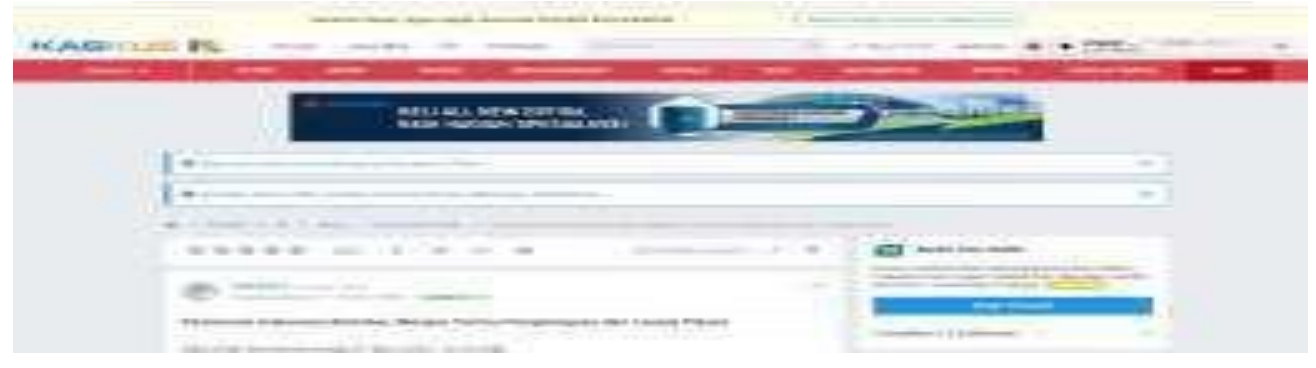

Gambar 14. web forum 


\section{Mobile Applications}

Mobile applications adalah aplikasi mobile yang didesain khusus untuk perangkat smartphone dan tablet. Platform aplikasi mobile ada 4 yaitu android, ios, windows 8 dan windows phone. Aplikasi yang dikembangkan yang berbasis mobile adalah seperti pemesan tiket pesawat atau hotel yang mana bisa dilakukan lewat telepon pintar.

Dengan perkembangan mobile yang sekarang semua informasi kita dapatkan dari mobile dan transaksi bisa dilakukan secara mobile. Aplikasi mobile ini sudah terintergrasi satu sama lainnya seperti pemesan hotel bisa dilakukan secara mobile tanpa perantara staf hotel dari proses cekin sampai proses cek out. Dengan adanya system yang terintegrasi dan terupdate secara real time baik itu berupa content, gambar, animasi maupun video atau suara akan mempermudah untuk mempromosikan pariwisata secara digital. Satu sisi akan memanjakan pelanggan atau wisatawan untuk mencari tempat-tempat yang diinginkan tanpa perlu lagi ke travel agent. Dan dari sisi bisnis akan mengurangi biaya operasional, lebih cepat dan lebih professional serta informasi yang disampai bisa langsung seluruh dunia mengetahuinya.

\section{SIMPULAN DAN SARAN}

\subsection{Simpulan}

1. Program yang digunakan dalam rangka perkembangan pariwisata Indonesia untuk menghadapi destinasi wisata berkonsep kekinian melalui pendekatan digital

Dari sisi strategi, pariwisata Indonesia berkembang dan maju berkat konsep tiga A (3A), yaitu atraksi, amenitas, dan aksesibilitas. Selama ini, promosi sudah dilakukan dengan gencar. Baik di dalam negeri maupun luar negeri. Baik secara offline maupun digital, terutama digital. Adapun dalam rangka perkembangan pariwisata Indonesia untuk menghadapi destinasi wisata berkonsep kekinian melalui pendekatan digital dapat dilakukan dengan tiga program, program ini sejalan dengan penjelasan Menteri Pariwisata yang telah merancang dan mengumumkan tiga program tersebut dalam upaya pengembangan pariwisata digital untuk kaum millenial yakni Wonderful Startup Academy, Nomadic Tourism dan Destinasi Digital

2. Peran pariwisata dalam menghadapi revolusi industri di era ekonomi digital

Pemanfaatan digital marketing di Era industri ekonomi digital, sangat berperan dalam meningkatkan promosi pariwisata. Digital marketing merupakan suatu keharusan karena generasi ini yang sering digunakan baik disadari maupun tidak. Aplikasi Digital marketing yang akan digunakan diantaranya website, media sosial, online advertising, web forum, mobile aplikasi. Digital marketing kedepannya adanya aplikasi yang memudahkan wisatan untuk melakukan travel dengan system yang otomatis dan adanya multi bahasa. Pemanfaatan digital marketing di era pada dunia pariwisata bukan hanya akan mengubah paradigma industri, namun juga pekerjaan, cara berkomunikasi, berbelanja, bertransaksi, hingga gaya hidup.

\subsection{Saran}

1. Agar perkembangan pariwisata Indonesia berkonsep kekinian melalui pendekatan digital dapat berkembang efektif pemerintah harus bisa menjalankannya dengan serius dan bukan hanya wacana saja dengan melibatkan organisai-organisai terkait seperti Genpi dan seluruh masyarakat Indonesia khususnya generasi kekinianyakni generasi z.

2. Agar Pariwisata dapat berperan aktif di dunia digital pemerintah Indonesia tidak boleh tertinggal dengan negara Jepang, Jerman dan Amerika Serikat yang sudah selangkah lebih maju yakni sudah di era 5.0. Harus lebih ditingkatkan sistem pariwisata Indonesia dengan menggandeng orang-orang cerdas di dunia digital dan perlu diadakan kerjasama dengan negara lain agar dunia pariwisata Indonesia dapat lebih dikenal seluruh dunia sehingga banyak wisman yang berwisata ke Indonesia dan meningkatkan pendapatan devisa negara Indonesia.

\section{DAFTAR PUSTAKA}

Ahmad Rosyidi Syahid , (2015), Arti Kata Tourism dan Pariwisata Ternyata Tidak Sama, (Retrifed from :https://studipariwisata.com/serba-serbi/arti-kata-tourism-dan-pariwisata-ternyata-tidak-sama/ 5/4/2019) 
Alif, (2015), Pengertian Tourism , (Retrifed from: http://alifeduca.blogspot.com/2015/06/pengertianpariwisata-tourism.html /5/4/2019

Badan Riset Statistik , (2019), Perkembangan Pariwisata dan Transportasi Nasional Februari 2019, No. 29/04/Th.XXII, $\quad 01 \quad$ April $2019 \quad$ Retrifed from https://www.bps.go.id/pressrelease/2019/04/01/1610/jumlah-kunjungan-wisman-ke-indonesiafebruari-2019-mencapai-1-27-juta-kunjungan.html 5/4/2019)

Bambang Pratama. (2018) Perubahan dan Tantangan Hukum Menghadapi Industri 4.0, (Retrifed from:http://business-law.binus.ac.id/2018/07/07/perubahan-dan-tantangan-hukum-menghadapiindustri-4-0/ 5-3-2019)

Digital marketing pariwisata (DMP), (2018). No Title. (Retrieved from http://digitalmarketingpariwisata.com/web/ 5/4/2019)

Fens Alwino. (2018) Kecerdasan Hukum Respon Revolusi Industri 4.0 (Retrifed from: http://www.stagingpoint.com/read/2018/11/14/151205/ Kecerdasan.Hukum. Respons.Revolusi.Industri.4.0/ 3-3-2019)

Hendra Suwardana. (2017) "Revolusi Industri 4. O Berbasis Revolusi Mental, JATI UNIK, 2017, Vol.1, No.2, Hal. 102-110 ISSN : 2597-6257

I Gede Agus Krisna Warmayana, (2018), Pemanfaatan Digital Marketing dalam Promosi Pariwisata pada Era Industri 4.0, Jurnal Pariwisata Budaya Vol 3, No. 2, Tahun, 2018 Hal 81-92.

Karinov, (2019), Revolusi Industri 5.0 ala Jepang: Human-Centered Society, ( Retrifed from : https://karinov.co.id/revolusi-industri-5-jepang/ 5/4/2019)

Kementrian Kominikasi dan Informatika RI, (2018).Pengguna Internet No 6 Di Dunia. (Retrieved from: https://kominfo.go.id/content/detail/4286/pengguna-internet-indonesia-nomor-enamdunia/0/sorotan_media 5/42019)

Lea, John P. (1994). August, 3-6. Conference Tourism and the Delivery of Positive Development. A paper presented at Rethinking Tourism seminar in Bali.

Muhamad Sidiq Wicaksono, Dwi Yunitasari, (2018), Efektifitas Endorse Dalam Promosi Pariwisata Indonesia, Jurnal Gama Societa, Vol. 1 No. 1, Januari 2018, Hal 1-8.

Soerjono, Soekanto. (2008) Pengantar Penelitian Hukum. Jakarta: UI Press.

The First Tourism startp Incubation Program In Indonesia, (Retrifed from : http://wonderfulstartupacademy.id/ 5/4/2019)

Undang-undang No 10 tahun 2009 Tentang Kepariwisataan, Lembaran Negara RI Tahun 2009 Nomor 11, TLN Nomor 4966.

Undang- Undang Republik Indonesia Nomor 9 tahun 1990 tentang Kepariwisataan, Lembaran Negara RI Tahun 1990 Nomor 78.

Van der Veen, R., \& Song, H. (2010). Exploratory Study of the Measurement Scales for the Perceived Image and Advertising Effectiveness of Celebrity Endorsers in a Tourism Context. Journal of Travel \& Tourism Marketing, 27(5), 460-473. ( Retrifed from : https://doi.org/10.1080/10548408.20 10.499059 $1 / 4 / 2019)$

Yoeti A. Oka. (1992). Anatomi Pariwisata.Bandung: Angkasa.

Yoeti A. Oka. (1995). Ekonomi Pariwisata Introduksi Informasi danImplementasi. Jakarta: PT. Gramedia Pustaka Utama

Yoeti, O. A. (1996). Pengantar Ilmu Pariwisata, Bandung : Angkasa

Zetria Erma dan Yuanita, (2018), Peranan Hukum Dalam Pembangunan Industri Nasional Pada Era Revolusi Industri 4.0, vol 1No.1 ( Retrifed from : http://www.ejournal.upmi.ac.id/index.php/snei/article/view/41 / 5-3- 2019) 